\title{
MoBILITÁSI SZÁNDÉKOK ÉS REZILIENCIA
}

\author{
HÖRICH BALÁZS
}

Debreceni Egyetem, Humán Tudományok Doktori Iskola

\begin{abstract}
A mobilitási lehetőségek és igények, valamint az oktatási rendszer funkciói szorosan összefüggnek. Fontos kérdés, vajon egy-egy képzéstípus kiszolgálja-e kliensei társadalmi igényeit. A magyar szakképzési rendszer egyre inkább kettészakad: míg az érettségit nyújtó képzésekben lehetőséget látnak a tanulók az előrelépésre, addig az érettségit nem adó képzések teljes zsákutcát jelentenek egy homogén társadalmi rétegnek. Ráadásul, a szakközépiskolák kliensei pont azokból kerülnek ki, akik számára jelenleg nem körvonalazódik az iskolai mobilitási csatornán kívül egyéb mobilitási lehetőség. Ilyen környezetben a lemorzsolódás, a korai iskolaelhagyás és az iskolai reziliencia vizsgálata kulcskérdés, hiszen ezek az atipikus tanulói magatartások áshatják alá leginkább egyegy képzéstípus legitimitását. Jelen tanulmányban az iskolai reziliencia és a mobilitási szándék összefüggését keressük. Az Országos kompetenciamérés (OKM) 2016. évi 10. évfolyamos tanulói adatbázisának felhasználásával háromféle rezilienciaszámítást ismertetek. Azt vizsgálom, hogy miként alakul a reziliencia mértéke azok között, akik státuszmegőrzési szándékot vagy felfelé irányuló mobilitási vágyat fogalmaznak meg. Eredményeim szerint a mobilitási szándék és a reziliencia mértéke összefügg.
\end{abstract}

Kulcsszavakः társadalmi mobilitás, iskolai reziliencia, Országos kompetenciamérés

Mobility opportunities and needs, and the functions of the educational system are closely connected. An important question is whether given training-types serve the social needs of their clients. The Hungarian vocational training system has become increasingly divided: while students see advancement potential in trainings that provide a general certificate of education, trainings that do not provide one mean a dead-end for a homogenous social stratum. Furthermore, clients of secondary vocational schools are already those whose sole mobility opportunity is educational mobility. In such an environment the issues of early school leaving and dropout, educational resilience are crucial since these atypical student behaviours can undermine the legitimacy of at least certain training types. The present research examines the relationship between educational resilience and mobility intentions. Relying on the 10th grade student database of National Assessment of Basic Competencies (OKM) 2016, I detail three types of resilience calculations. I examine

Levelező szerző: Hörich Balázs, Debreceni Egyetem, Humán Tudományok Doktori Iskola,

4032 Debrecen, Egyetem tér 1. E-mail: horichb@gmail.com 
different degrees of resilience among those with status-preservation and with upward mobility intentions. The results show that resilience and mobility intentions correlate.

Keywords social mobility, educational resilience, National Assessment of Basic Competencies

$\mathrm{A}$ reziliencia először mint természettudományi, majd mint ökológiai, illetve pszichológiai szakkifejezés jelent meg dominánsan a tudományos diskurzusokban, ám manapság már a többféle tudományos diszciplinában megtaláljuk e fogalmat, illetve a mögötte felsejlö megközelítést (Tóth et al. 2016; Székely 2015; Szokolszky-V. Komlósi 2015). A kutatások fókuszában az áll(t), hogy milyen mechanizmusok alakítják ki a reziliens viselkedést, illetve mely védőfaktorok akadályozzák meg a tipikus és elvárt tüneteket. Az iskolai reziliencia (educational resilience, academic resilience) vizsgálata nem hosszú múltra tekint vissza, lényegében az elmúlt évtizedekben fordult ebbe az irányba a hazai és nemzetközi neveléstudományi, illetve oktatásszociológiai érdeklődés.

$\mathrm{A} z$ iskolai reziliencia és a méltányos oktatás fogalomköre elválaszthatatlan egymástól. A méltányos oktatás alapgondolata túlmutat az esélyegyenlőségi megközelítésen: lényege, hogy származástól, társadalmi-gazdasági státuszától függetlenül mindenkinek lehetőséget kell biztosítani vágyainak, elképzeléseinek és képességeinek megfelelő kibontakoztatására (Révai 2015). Míg az esélyegyenlőségi a bemeneti, a méltányossági megközelítés a kimeneti mutatókra, indikátorokra fókuszál (Papp 2015; OECD 2013).

Egy tanuló társadalmi-gazdasági háttere jelentősen meghatározza teljesítményét (lásd például OECD 2010, 2013, 2016). A reziliencia arra vonatkozik, hogy egy tanuló túl tud-e lépni ezen a meghatározottságon, képes-e a családi hátterétől függetlenül jól teljesíteni. A reziliencia számítása többféleképpen történhet (OECD 2010, 2013, 2016; CsüllögLannert-Zempléni 2015; Agasisti et al. 2018; Tóth et al. 2016).

A nemzetközi összehasonlításra alkalmas PISA-vizsgálatok szerint Magyarországon mindhárom mérési terület (szövegértés, matematika, természettudomány) esetében az OECD-átlag alatt marad a reziliens tanulók aránya. A legnagyobb mértékü különbség a természettudományi területen jelentkezik, ráadásul ezen a területen 2006-hoz képest jelentős romlás is tapasztalható: míg 2006-ban csak 1,7 százalékpont volt a különbség (OECD: 27,7\%, Magyarország: 26\%), addig 2016-ben már 9,9 százalékpont (OECD: 29,2\%, Magyarország: 19,3\%) (OECD 2016). Jellemző, hogy a magas PISA mérési eredmények együtt járnak a reziliens tanulók magasabb arányával, azaz a méltányosság és a teljesítmény összefügg egymással (Papp 2015).

\section{Mobilitási elképzelések és az iskolai reziliencia}

Hipotézisem az, hogy a mobilitási percepciók összefüggnek azzal, hogy egy tanuló reziliens lesz-e vagy sem. Az összefüggés irányát azonban nehéz egyértelműen kimutatni. Korábbi elemzések (Csüllög-Lannert-Zempléni 2015) rámutattak arra, hogy minél közelebb van valaki az iskolai pályafutást követő pályakezdéshez, annál kevésbé érezhető a családi háttér hatása, és annál inkább előkerülnek a racionális mérlegelő szempontok. 
Azaz, minél későbbi mérési eredményt vizsgálunk, annál nehezebb eldönteni, hogy valaki azért lesz reziliens (sok más befolyásoló szempont mellett), mert a szülőkhöz képest előrébb szeretne jutni a társadalmi hierarchián, vagy azért tűz ki maga elé mobilitási célt, mert tisztában van saját képességeivel. Ezt a problémát ebben a tanulmányban nem is igyekszem feloldani. Ugyanakkor feltétezem, hogy olyan iskolai közegben, ahol a tanulók mobilitási lehetőségei tágabbak, ott a reziliensség összekapcsolódik a társadalmi mobilitás vágyával (gimnáziumi és szakgimnáziumi képzéstípus), ott pedig, ahol nincs érdemi lehetőség (vagy az igen nagy befektetést igényel) ott nem láthatunk összefüggést (szakközépiskolai képzés).

A hipotézis vizsgálatát a 2016. évi Országos kompetenciamérés (továbbiakban: OKM) 10. évfolyamos tanulói adatbázisán végeztem el. Csak azokat a tanulókat vettem figyelembe, akik érvényes matematikai és szövegértési teszteredménnyel rendelkeznek, illetve a háttérkérdőív lehetőséget biztosított arra, hogy az Oktatási Hivatal családi háttérindexet rendeljen a tanulóhoz (ez a teljes, az OKM 10. évfolyamos mérésébe bevont tanulói populáció 80 százaléka). A könnyebb áttekinthetőség miatt összevontam a 4, a 6 és a 8 osztályos gimnáziumokat („gimnáziumi képzések”) és kihagytam az elemzésből a speciális készségfejlesztő szakiskolákat.

Független változóként két változót vontam be: az apa iskolázottságát, illetve a mobilitási elképzeléseket. Előbbi változót négykategóriás változóként vettem figyelembe (legfeljebb 8 általános, szakmunkás, érettségizett vagy diplomás). A mobilitási elképzeléseket közvetlen módon nem méri az OKM-hez kapcsolt háttérkérdöív, de az megkérdezésre kerül, hogy milyen iskolai végzettséget szeretne elérni a vizsgálatba került tanuló. A válaszkategóriákat három csoportba soroltam: legfeljebb szakvégzettség, érettségi vagy diploma. A hipotézisvizsgálatban a függő változó az, hogy reziliens-e a tanuló vagy sem. A függetlenséget Chi-négyzet teszttel, illetve a kompetenciamérések átlagai esetén F-próbával vizsgáltam. Ahogy a szakirodalmi ismertetésből kiderült, korántsem egységes, hogy mit tekintünk reziliensnek: a fö kérdés itt az, hogy az összes tanulóra vonatkoztassunk-e, vagy az adott képzéstípusban járók körében válogassuk-e le a kiemelkedő teljesítményű tanulókat. Emiatt három modellt ismertetek. Az elsőben a "hagyományos” megközelítéssel definiáltam a rezilienciát: az összes tanuló családi hátterének figyelembevételével azokat az alsó negyedbe tartozó diákokat számítottam ide, akikknek a teljesítménye (szintén az összes tanuló figyelembevételével) a legfelső negyedbe tartozik. A második modellben tágabban értelmezem a reziliensek körét: nem kvartiliseket, hanem terciliseket határoztam meg, így vélhetően az iskolatípusok közötti különbségek is tompulnak. A harmadik modellben pedig az adott képzéstípusban tanulók várt és tényleges teljesítménykülönbségeinek (reziduumainak) különbségét vettem figyelembe a kvartilisek kialakításánál. Ez utóbbi modell tehát relativisztikus, hiszen azokat a tanulókat emeli be a reziliensek közé, akik saját iskolai közegükhöz képest mutatnak kimagasló teljesítményt.

Hipotézisem általános értelemben akkor igazolódik, ha azon csoportok esetében nagyobb a reziliensek aránya, akik „felfelé” irányuló mobilitási pályát tűznek ki célul, azaz magasabb iskolai végzettséget szeretnének elérni, mint apjuk iskolázottsága. Az apa iskolázottságára és az iskolai célkitűzést firtató kérdésre adott érdemi válaszokat figyelembe véve a felmérésben részt vevők 63,4\%-a felfelé irányuló mobilitást tüzött ki célként, 32,9\% státuszmegőrzésre törekedett, míg 3,7 százalékuk alacsonyabb iskolázottságot akart megszerezni (1. táblázat). Mindhárom képzéstípus esetén igaz, hogy többségben vannak 
azok, akik apjuknál magasabb iskolázottságot szeretnének elérni, ám az is látszik, hogy a státuszmegőrzők aránya a gimnáziumi képzésben (40,1\%), illetve a szakközépiskolai képzésben (37,1\%) viszonylag magas. Előbbi esetben arról van szó, hogy nincs hova felfelé lépni (diplomás szülők gyerekei), utóbbiban pedig inkább nincs rá akarat vagy nem látnak rá lehetőséget.

1. táblázat: Az apa iskolázottsága és a tanuló iskolázottsági célkitűzése (\%), $N=64196$

\begin{tabular}{lcccc}
\hline \multirow{2}{*}{ Apa iskolázottsága } & \multicolumn{2}{c}{ Tanuló iskolázottsági célkitüzése } & Összesen \\
\cline { 2 - 4 } & legfeljebb szakmunkás & érettségi & diploma & \\
\hline legfeljebb 8 általános & 3,3 & 4,9 & 1,9 & 10,1 \\
szakmunkás & $\mathbf{6 , 0}$ & 19,2 & 18,0 & 43,2 \\
érettségi & 0,9 & 7,6 & 16,1 & 24,6 \\
diploma & 0,4 & 2,4 & $\mathbf{1 9 , 3}$ & 22,1 \\
\hline Összesen & 10,6 & 34,1 & 55,3 & 100,0 \\
\hline
\end{tabular}

Forrás: OKM 2016, tanulói adatbázis (10. évfolyam)

\section{Kvartilis rezilienciamodell}

$\mathrm{A} z$ iskolai reziliencia mérésére vonatkozó legszükebb megközelítés esetében az összes, vizsgálatba bevont tanuló mindössze 1,6 százaléka tartozik a matematika területén kimagasló teljesítményü tanulók közé. Ez az arányszám a szakgimnáziumi képzésben résztvevők körében a legmagasabb (2,2\%), a szakközépiskolai tanulók körében pedig a legkisebb (0,7\%). Mindez azt is jelenti, hogy a reziliensek fele szakgimnáziumi, 41,8\%-a pedig gimnáziumi képzésben vesz részt, szakközépiskolába pedig csak 8 százalékuk jár. Ha a tesztek eredményeit is nézzük, a matematikai kompetenciaterületen alig van különbség a különböző képzéstípusba járó reziliens tanulók eredményei között. A szövegértés területén hasonló arányszámokat látunk, igaz, a mért eredményekben viszont jelentős differenciák vannak (2. táblázat).

A gimnáziumi és a szakgimnáziumi képzések esetén igaz, hogy a felfelé irányuló mobilitási célkitűzéssel jellemezhető tanulók körében magasabb a reziliens tanulók aránya azokhoz képest, akik legfeljebb státuszmegőrzésben gondolkodnak. A szakközépiskolai tanulók esetében ez az összefüggés nem áll fent, a reziliencia mértéke független a mobilitási szándékoktól. Ez a tendencia mind a matematikai, mind a szövegértési kompetenciaterület esetén megfigyelhető. Ugyanakkor jellemző az is, hogy az elért teljesítményben (azaz a kompetenciamérés eredményében) nincs különbség: a mobilitási szándék a reziliencián belül nem okoz többletteljesítményt (3. táblázat).

\section{Tercilis rezilienciamodell}

A tercilisek szerinti felosztásban az összes tanuló 4,1\%-a a matematika és 3,7\%-a a szövegértés területén reziliens. A matematika területén valamivel nagyobb arányban találjuk a szakgimnáziumi reziliens tanulókat a gimnáziumi reziliensek arányához képest, a szövegértési kompetencia terén arányuk azonos. A szakközépiskolai tanulók mindössze 


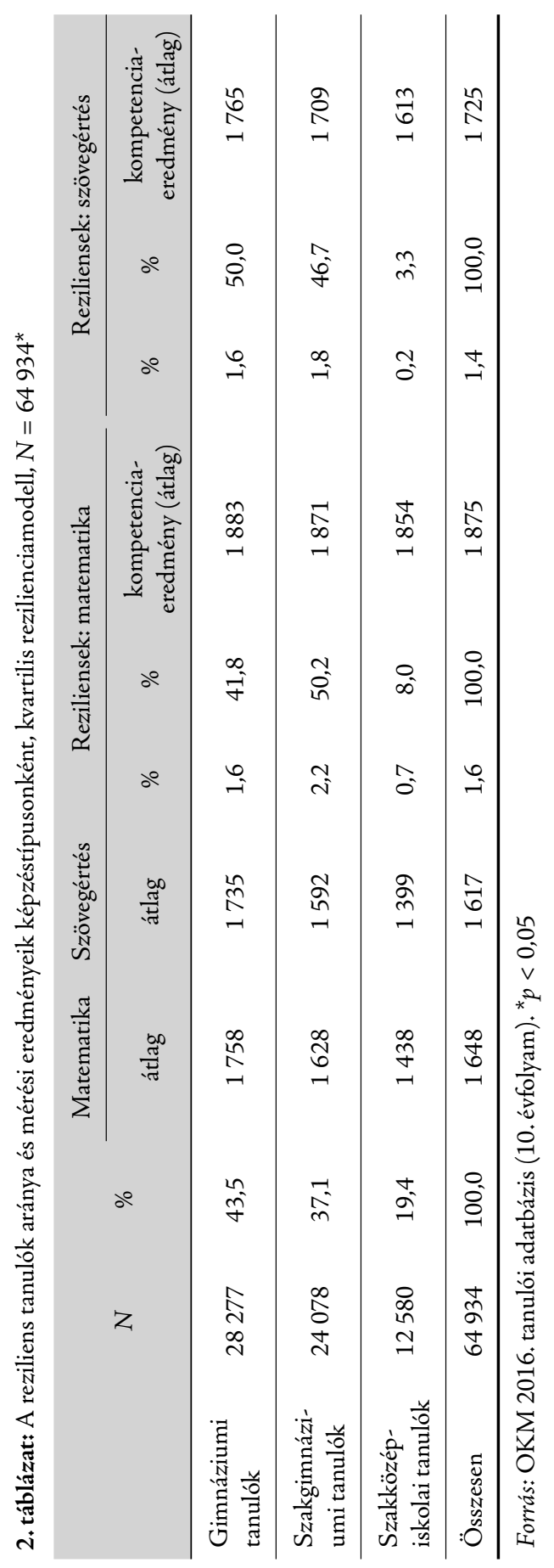




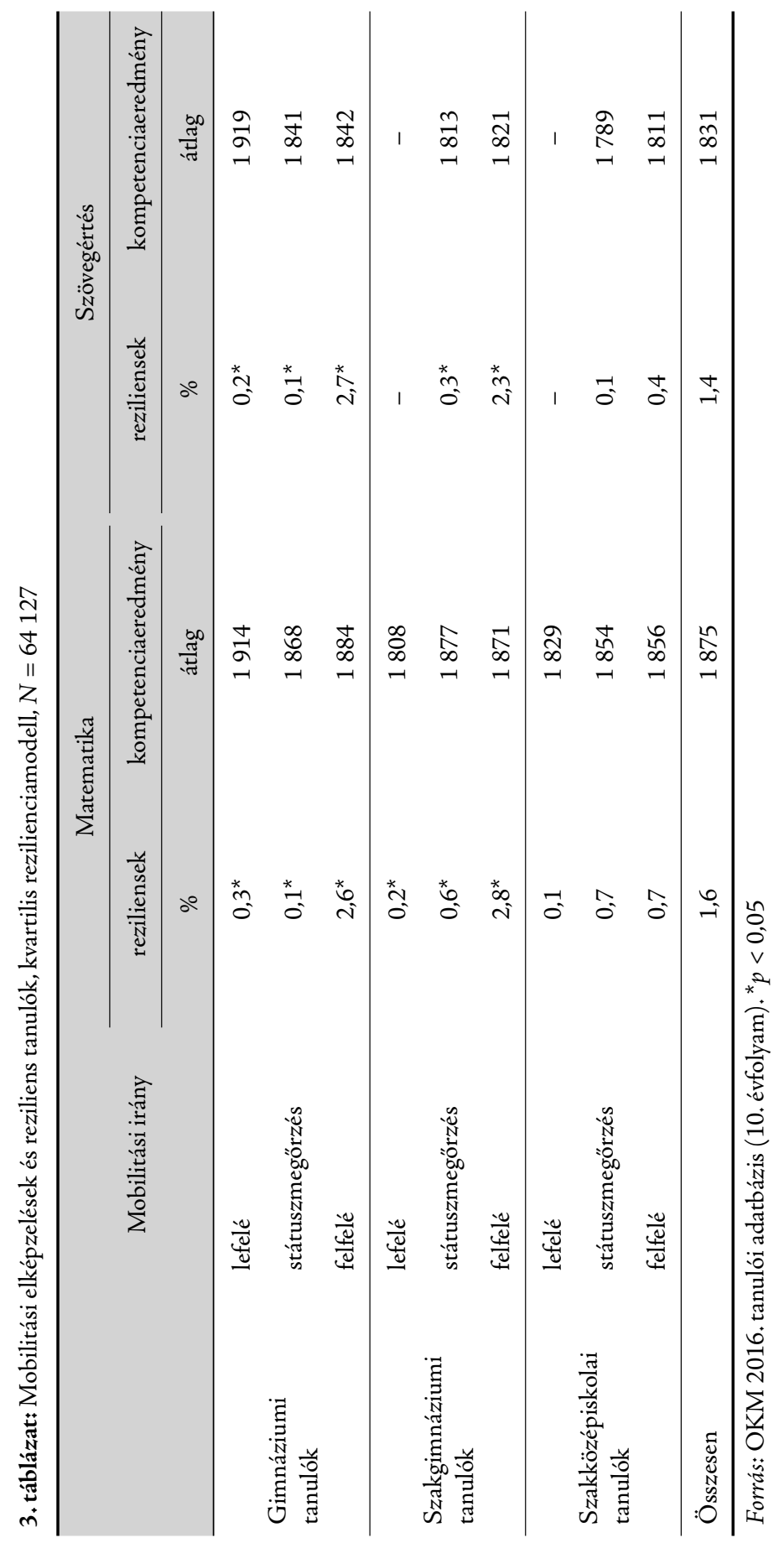




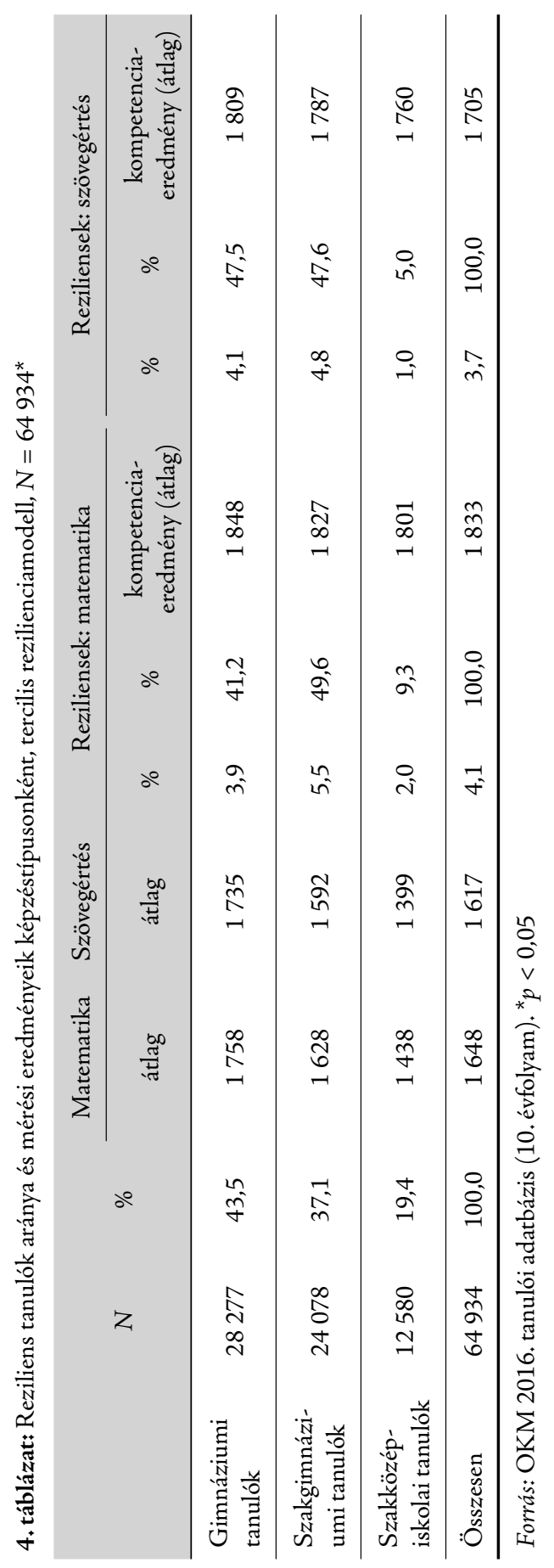




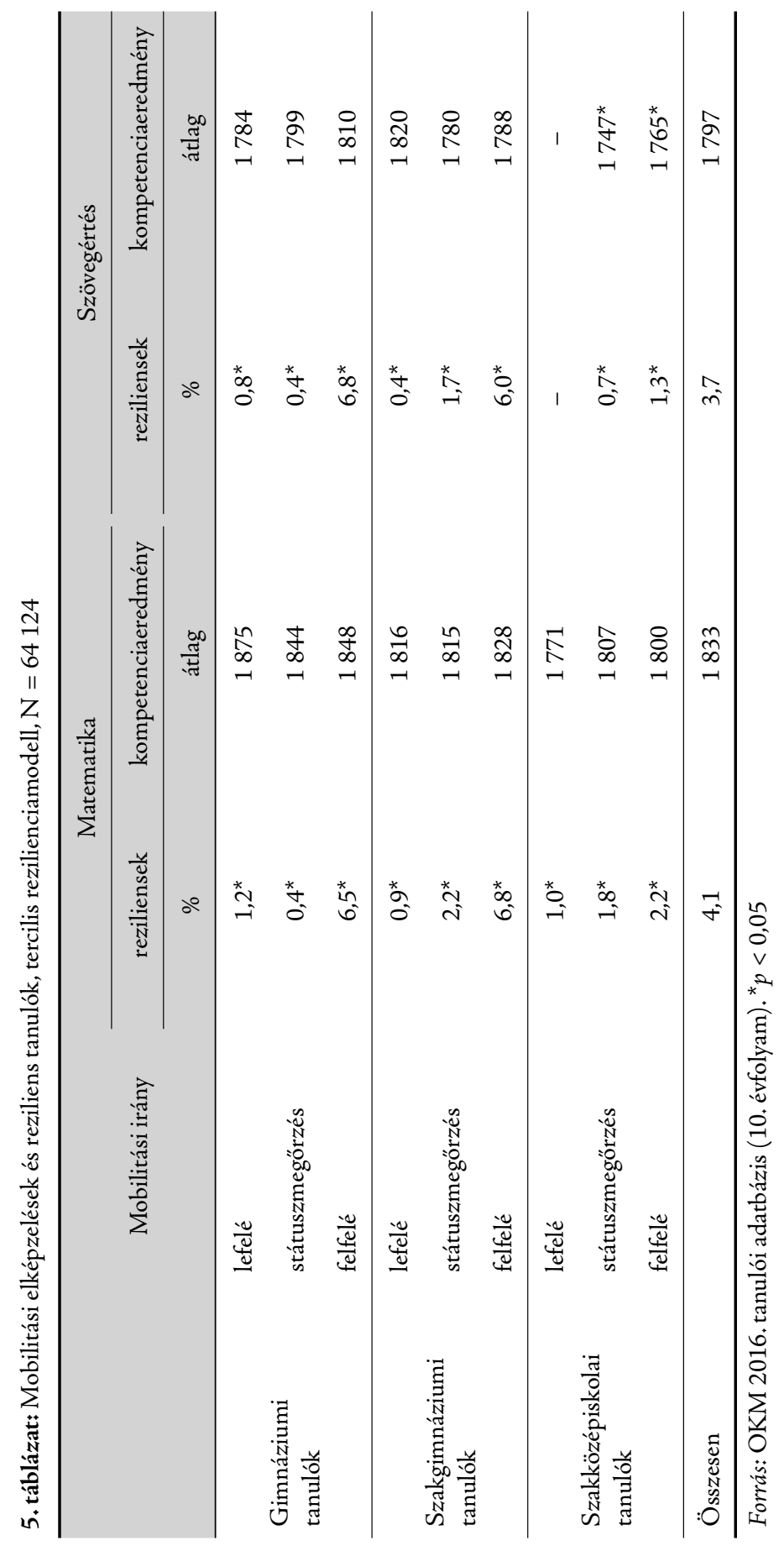


1-2 százaléka fér be a tágabban értelmezett rezilienciameghatározás alá. A kompetenciamérések eredményeiben már valamivel nagyobb a heterogenitás, azaz attól függően, hogy milyen képzéstípusba járó reziliens tanulót nézünk, az elért teljesítmény különbözik (a gimnáziumokban tanulók esetében a legjobbak, a szakközépiskolákban tanulóknál pedig a leggyengébbek a mérési átlagok) (4. táblázat).

Ebben a modellben is ugyanazokat az összefüggéseket figyelhetjük meg, mint az elsőben: a felfelé irányuló mobilitási szándékot jelző gimnáziumi és szakgimnáziumi tanulók körében nagyobb, a szakközépiskolai tanulók körében pedig lényegében azonos a reziliens tanulók aránya azokhoz képest, akik inkább státuszmegőrzésben gondolkodnak. A teszteredményekben továbbra sincs érdemi különbség az egyes mobilitási csoportok között (5. táblázat).

\section{Relatív rezilienciamodell}

A harmadik modellben a reziliens tanulókat úgy határoztuk meg, hogy képzéstípusonként kiszámoltuk a tisztán családi háttérből fakadó becsült teszteredményeket. A lineáris regressziós becslések a következő képletek alapján történtek (6. táblázat).

6. táblázat: Lineáris regressziós egyenletek képzéstípusonként és kompetenciaterületenként

\begin{tabular}{llc}
\hline & \multicolumn{1}{c}{ Matematika } & Szövegértés \\
\hline Gimnáziumi képzések & $y=1711,936+82,076 x$ & $y=1691,972+76,786 x$ \\
Szakgimnáziumi képzések & $y=1633,427+53,506 x$ & $y=1596,123+47,864 x$ \\
Szakközépiskolai képzések & $y=1478,703+46,768 x$ & $y=1436,343+43,272 x$ \\
\hline
\end{tabular}

Forrás: OKM 2016. tanulói adatbázis (10. évfolyam)

A becslések és a tényleges eredmények különbségét, a reziduálisokat négy egyenlő részre osztottuk. Azokat tekintettük reziliens tanulóknak, akik családi hátterük szerint a legalsó, reziduumuk szerint pedig a legfelső kvartilisbe kerültek.

A matematikai kompetenciaterületen a reziliensek aránya 6,3, a szövegértési területen pedig 6,5\%. Mivel a teljes minta családi hátterének kvartiliseit vettük alapul, a reziliensek aránya jelentős mértékben torzít a szakközépiskolai szegmens felé, de ez lehetőséget ad arra, hogy a képzéstípuson belül törésvonalak felszínre kerüljenek. Nyilvánvaló, ha a családi háttér független lenne a képzési programban való részvételtől (illetve a korábbi iskolai úttól), akkor a reziliensek aránya körülbelül ugyanakkora lenne mindhárom programban. Mindenesetre a gimnáziumi képzésben lévő reziliensek aránya 2,3 , illetve $2,2 \%$, a szakgimnáziumokban 5,8 és $6,5 \%$, a szakközépiskolákban pedig 16,3 és 16\%. A reziliens tanulók közel fele tehát szakközépiskolákban, közel négytizede pedig szakgimnáziumokban tanul. A gimnáziumi és szakgimnáziumi tanulók mérési eredményeiben körülbelül 60-80 pont különbség van, a szakgimnáziumi és szakközépiskolai tanulók eredményei között pedig ennek két-háromszorosa: ahhoz tehát, hogy egy szakközépiskolai tanuló kitűnjön iskolatársai közül, relatíve kevesebb teljesítmény is elég (7. táblázat). 


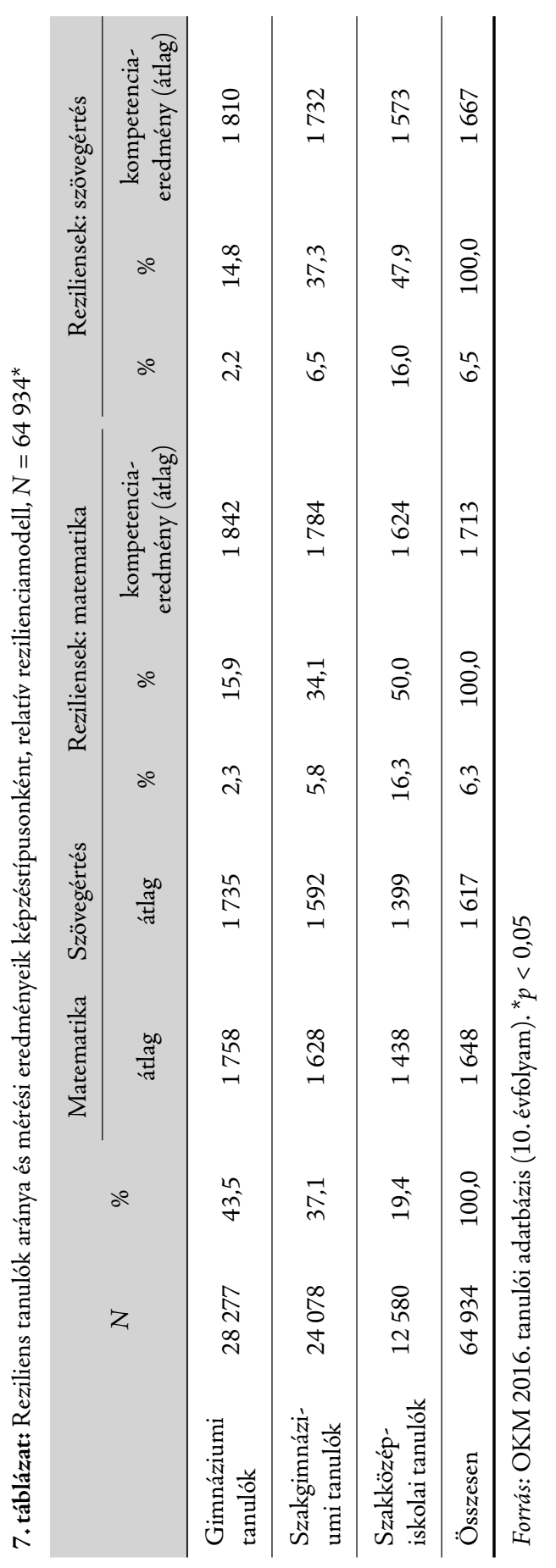




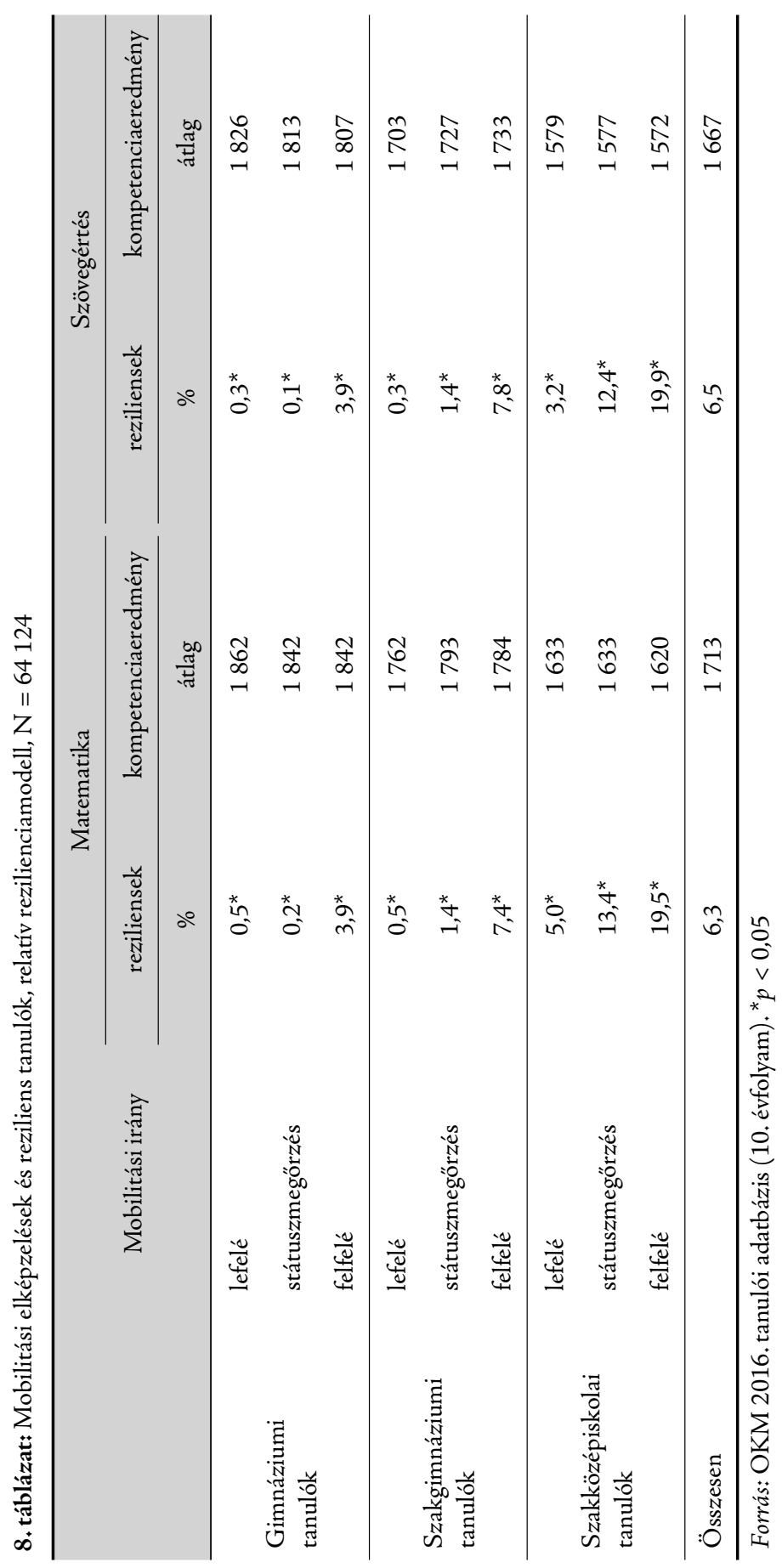


Mindhárom képzési programra jellemző, hogy a mobilitási aspirációval rendelkezők körében magasabb a reziliens tanulók aránya. A szakközépiskolai tanulók esetében a státuszmegőrzésre törekvők körében is magas a relatív reziliencia, de az apjuk iskolázottságánál többet elérni igyekvőknél még magasabb ez az arány. Azaz, ha a kiemelkedő képességet az adott képzési közegen belül értelmezzük, akkor a mobilitási vágy ugyanúgy összekapcsolódik a rezilienciával szakközépiskolai szinten is: a legfeljebb 8 osztályt végzett apák felfelé mobil gyerekeinek 23,1 százaléka reziliens. Ez azt is jelenti, hogy a magasabb lépcsőfokon történő mobilitás (például szakmunkás apa gyereke érettségit vagy diplomát céloz meg) kevésbé kapcsolódik össze kiemelkedő kompetenciaeredményekkel (8. táblázat).

\section{Összegzés - a reziliens tanulók felfelé irányuló mobilitása}

Azt feltételeztem, hogy a mobilitási szándék és a reziliencia összefügg, de képzéstípusonként eltérő mértékű. Hipotézisemet három rezilienciamodell alapján ellenőriztem. Az első modellben a reziliens számítások „hagyományos” módjával éltem, a másodikban kvartilisek helyett terciliseket használtam, a harmadikban pedig relatív rezilienciával számoltam. Az első két modell teljes mértékben alátámasztotta feltételezésemet, a harmadik csak részben. A reziliencia és az apa iskolázottságának meghaladásában mért mobilitási szándék összefügg, igaz, az ok-okozati viszony nem tisztázott. A gimnáziumi és a szakgimnáziumi képzésekben a felfelé irányuló mobilitási szándék együtt jár a reziliens tanulók magasabb arányával. Amennyiben a rezilienciát mint kimagasló teljesítményt az összes tanuló teljesítményének függvényében mérjük, a mobilitási szándékot mutató szakközépiskolai tanulói kör tagjai körében ugyanakkora a reziliensek aránya, mint azok között, akik státuszmegőrzést tűztek ki célul. Amennyiben a rezilienciát képzéstípuson belül értelmezzük, a szakközépiskolások esetében is megfigyelhető, hogy a mobilitási szándékkal szorosabban együtt jár a jobb teljesítmény is. Ugyanakkor, ha kérdésünket úgy fogalmazzuk meg, hogy egy reziliens tanulóhoz milyen valószínűséggel társul felfelé irányuló mobilitási szándék a státuszmegőrzési elképzeléshez képest, az egyes képzéstípusok között nagymértékü különbségek láthatók - attól függetlenül, hogyan határozzuk meg a reziliens kritériumát (9. táblázat).

9. táblázat: Reziliens tanulók körében a felfelé irányuló mobilitási szándékról beszámolók gyakorisága a státuszmegörzésre törekvő tanulókhoz képest, szorzók

\begin{tabular}{llrcr}
\hline & & Kvartilis & Tercilis & Relatív \\
\cline { 3 - 5 } & & \multicolumn{3}{c}{ rezilienciamodell } \\
\hline \multirow{3}{*}{ Matematika } & gimnázium & 26,0 & 16,3 & 19,5 \\
& szakgimnázium & 4,7 & 3,1 & 5,3 \\
& szakközépiskola & 1,0 & 1,2 & 1,5 \\
\hline \multirow{3}{*}{ Szövegértés } & gimnázium & 27,0 & 7,7 & 39,0 \\
& szakgimnázium & 7,7 & 3,5 & 5,6 \\
& szakközépiskola & 4,0 & 1,9 & 1,6 \\
\hline
\end{tabular}

Forrás: OKM 2016. tanulói adatbázis (10. évfolyam) 
A relatív rezilienciamodell szerint (matematika képességterületen mérve) míg egy gimnáziumba járó reziliens tanuló közel húszszor nagyobb gyakorisággal (eséllyel) törekszik az apjánál magasabb iskolai végzettség elérésére, addig egy szakgimnáziumba járónál ez a szorzó 5 körül, egy szakközépiskolai tanuló esetén pedig csupán 1,5 körül alakul. Mindez azt jelzi, hogy képzéstípusonként nemcsak a reziliens tanulók aránya különbözik jelentősen, hanem az is, mennyire támogató az intézményi (és az ahhoz kapcsolódó szociális) környezet a felemelkedéssel, kitörési lehetőségekkel kapcsolatban. A szakközépiskolák esetében alig látható ez a támogató környezet, ami végső soron a képzéstípus újabb válságtünetét jelzi.

\section{IRODALOM}

Agasisti, T., Avvisati, F., Borgonovi, F. \& Longobardi, S. (2018) Academic Resilience: What Schools and Countries Do to Help Disadvantaged Students Succeed in Pisa. OECD Working Paper No. 167. Paris, OECD Publishing. http://dx.doi.org/10.1787/e22490ac-en [Letöltve: 2019. 04. 01.]

Csüllög, K., LANnert, J. \& Zempléni, A. (2015) Számít a pedagógus és az iskola! A felülemelkedö (reziliens) tanulók teljesitményét befolyásoló tényezők az Országos kompetenciamérés adatai alapján. Budapest, Oktatási Hivatal.

OECD (2010) PISA 2009 Results: What Students Know and Can Do - Student Performance in Reading, Mathematics and Science. Vol. I. PISA. Paris, OECD Publishing. http:// dx.doi.org/10.1787/9789264091450-en [Letöltve: 2019. 04. 01.]

OECD (2013) PISA 2012 results. Excellence through Equity. Giving Every Student the Chance to Succeed. Vol. II. PISA, Paris, OECD Publishing. http://dx.doi. org/10.1787/9789264201132-en [Letöltve: 2019.04.01.]

OECD (2016) PISA 2015 Results. Excellence and Equity in Education. Vol. I. PISA. Paris, OECD Publishing. http://dx.doi.org/10.1787/9789264266490-en [Letöltve: 2019. 04. 01.]

PApp, Z. A. (2015) A méltányosság mérési lehetőségei. In: Lannert J. (ed.) A középiskolák összehasonlitó elemzése a KIR bázisán. Budapest, Oktatási Hivatal. pp. 124-153. http:// real.mtak.hu/31310/1/pza_Kozepiskola_kiadvany_4resz_A4.pdf [Letöltve: 2019. 04. 01.]

RÉvaI, N. (2015) Méltányosság az oktatásban - miről beszélünk? In: B. Tier N. (ed.) Alma a fán. Iskolavezetook a méltányos oktatásért. Budapest, Tempus Közalapítvány. pp. 10-29.

Székely, I. (2015) Reziliencia: a rendszerelmélettől a társadalomtudományokig. Replika, Vol. 94. pp. 7-23.

Szoкоцszкy, Á. \& V. Komıósı, A. (2015) A „reziliencia-gondolkodás” felemelkedése - ökológiai és pszichológiai megközelítések. Alkalmazott Pszichológia, Vol. 15. No 1. pp. 11-26.

Tóth, E., Fejes, J. B., Patai, J. \& Csapó, B. (2016) Reziliencia a magyar oktatási rendszerben egy longitudionális program adatainak tükrében. Magyar Pedagógia, Vol. 116. No. 3. pp. 339-363.

A cikk a Creative Commons Attribution 4.0 International License (https://creativecommons.org/licenses/ by/4.0/) feltételei szerint publikált Open Access közlemény, melynek szellemében a cikk bármilyen médiumban szabadon felhasználható, megosztható és újraközölhető, feltéve, hogy az eredeti szerző és a közlés helye, illetve a CC License linkje és az esetlegesen végrehajtott módosítások feltüntetésre kerülnek. (SID_1) 